\title{
BRIDGING PRACTICE: Design lessons for knowledge exchange between students and research in circular design
}

\author{
Laetitia Forsta, Cathryn Anneka Halla \\ aniversity of the Arts London \\ *Corresponding author e-mail: I.forst@arts.ac.uk
}

\begin{abstract}
:
Albert Einstein is famously quoted saying "I never teach my pupils; I only attempt to provide the conditions in which they can learn". This paper explores the conditions and adaptive methods used by practice design researchers to enable circular design knowledge exchange between a university research community and the student body. This paper explores and draws on the experience of the authors across three academic years (2018-2020) as PhD practice researchers at Centre for Circular Design (CCD). It unpicks the adaptive practice research approaches used by the authors which enabled them to set up and deliver a series of activities under the 'Circular Design Lab' an education and teaching platform at CCD. Through its creation it supported a thriving community of circular designers. Using reflective practice, the paper explores the authors practice design methods to create a bridge between emerging research practice and the taught courses.
\end{abstract}

Keywords: Practice Research Methods; Circular Design; Textile Design Education; Knowledge Exchange

\section{Introduction}

\subsection{Circular Design Education Context}

In the context of a climate emergency, the role of design is more crucial than ever in the transition to a sustainable future (Irwin, Kossoff and Tonkinwise, 2015). If designers should play such a vital role in this change, this must be reflected in design education. However, creating a bridge between new knowledge in the research community and the education of designers presents a major challenge.

This area of circular design is currently in its adolescence, with various schools of thought converging to define strategies for circularity such as, cradle-to-cradle principles (Braungart and McDonough, 
2002) and the Circular Economy (EMF, 2013). More recently a variety of research has been documented exploring the ways general circularity concepts can be transferred to university level curricula (Kirchherr and Piscicelli, 2019; Joāo, 2020). In addition, resources continue to be developed to aid students in designing for the circular economy, such as the Ellen McArthur Foundation learning hub (EMF, 2017) and 'Teaching Circular Design, A Handbook for Educators' (Joore et al., 2019). However, the space between circular design education and research is expanding to include engaging with social and behavioural change (Whitty, 2016).

Specifically in the field of fashion and textiles, researchers have developed a range of tools to aid students in designing both sustainably and circularly. For example, 'Textile Environmental Design' research group (now the Centre for Circular Design - CCD) developed a set of ten sustainable strategies which "serve as practical guidelines to examine, survey and highlight the problem of sustainability and the role of designers in change and innovation" (CCD, 2021). Since then, Design School Kolding (2018) have produced 26 'Sustainable Design Cards' to enable students to "negotiate and identify what they want to focus on in relation to sustainability" (Hasling and Ræbild, 2018:142). However, the translation of these resources and tools by educators and students into material, products and processes is not easy (Ibid, 2018). As researchers continue to expand on the nuances and depth within these sustainable and circular strategies, their manifestations in student and industry production can be explored in more detail (Earley, Vuletich, Hadridge, et al., 2016). The work presented here draws on the precedents of these tools to adapt their ethos of teaching circular design to the context of extra-curricular participative activities.

\subsection{Knowledge Exchange Context}

The improvement of knowledge transfer and more recently knowledge exchange between academia and education has long been an area of study. Becheikh et al. (2010) conducted a systematic literature review of the topic which acknowledged the importance of actors that can provide a link between the two realms. They recognise that in many cases "the complexity of the knowledge produced by researchers could make it difficult for practitioners to understand and adopt it" (ibid, 2010:15). To overcome this, they suggest that the role of 'linkage actors' that are involved in some form of academic training can be used to promote a culture of information-sharing and provide a space for critical thinking, questioning and debating. Specifically in the field of design, Follett and Marra (2012) argue design strategy can be used to support areas of knowledge exchange. Whereas, Mainsah, Morrison and Edeholt (2017) argue that creating networks plays a key role in meaningful exchanges between design students, teachers, and researchers.

In this paper the authors explore their response to a perceived lack of engagement of design students with the research community at University of the Arts London (UAL). It investigates the authors methods for creating cultures of knowledge exchange and draws on their own practicebased research methods to bridge the research at CCD with the student body. This was achieved by creating an education platform/network - 'Circular Design Lab' (CDL) - which formed a programme of extra-curricular activities, such as visits, talks, discussion and workshops.

Reflecting on the different types of CDL activities the paper demonstrates how practice research methods in design can influence the way we build thriving communities. Following the double diamond (Design Council, 2019) the paper presents the CDL activities in four stages: discover, define, develop, and deliver, providing methods for other design-educators to follow. Alongside this, the paper explores the enablers of these activities and offers a new perspective in how to bridge research and teaching in the changing field of circular design. 


\section{Methods}

The authors propose two sets of methods, the first being applied to the development of the CDL activities using a practice-research design approach, and the second applied to the creation of this paper using a reflective review approach to draw insights from the activities performed in the three years of the programme.

The CDL programme was developed following a double diamond approach, including activities which were aimed to inspire and expand perspectives for participants, then narrow and define the important questions for the field, develop and refine responses and deliver design prototypes and concepts. This overarching methodology was coupled with a 'bricolage' approach (Vuletich, 2015) that both authors had used in their own practice-based PhD research (Forst, 2020; Hall, 2021). The name bricolage was first used by Lévi-Strauss (1962:22) to signify "make do with 'whatever is at hand'". This suggests that multiple approaches can be tested and iterated inside a body of work to generate a bespoke set of methods. It provides the opportunity to experiment with a variety of formats and, just as a designer can be adaptive with the materials and tools in front of them, the CDL activities adapted to each year's situation including the appearance of a global pandemic. In this way, the PhD researchers took a 'learning through doing approach' (Dewey, 1997) involving 'reflection on action in action' (Schön, 1983:58) to evolve the formats across the three years. These approaches are explained in detail and related to individual events and activities further in this paper.

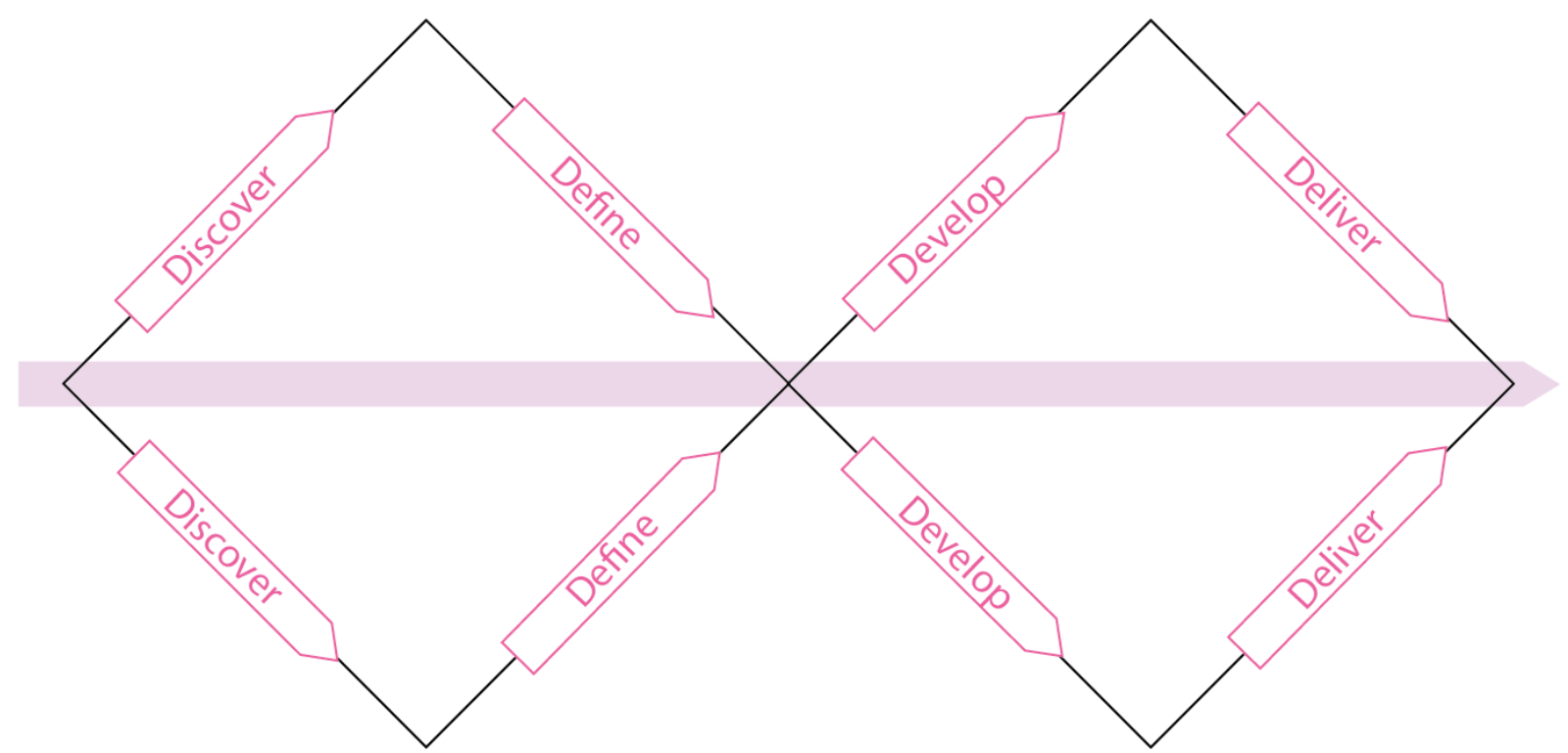

Figure 1. Double diamond of design innovation (adapted from Design Council, 2019)

To draw insights and recommendations from the body of work represented in the CDL programme, a reflective review, using the after-action review method (Morrison and Meliza, 1999; Earley and Forst, 2019) was performed. This asks simple questions such as "what happened?", "what went well?", or "what could be improved?" to articulate the challenges and successes of past events. This was used in conjunction with regular reports from the events, as well as with written testimonies from participants that were contacted by email. This approach has led to characterise the recommendations and limitations that are presented in this paper. 


\section{Circular Design Lab}

Circular Design Lab is an education and teaching platform comprised of two main strands; an interest group which encouraged the student body to engage in circular design conversations throughout the academic year and an annual symposium providing an intense injection of circular design inspiration and activities.

\subsection{There and Back Again Symposium}

CDL's 'There and Back Again' (TABA) symposium brought together students, industry, and research. The event was run for three consecutive years and adapted its last edition in 2020 to be online due to covid19 restrictions. The numbers of attendees in the events grew from 70 in person to 250 attendees online and ranged from students, to practitioners, industry, and researchers. The aim of the event was to bring knowledge of contemporary circularity challenges from the research centre and from other organisations to the students. It was also a space to disseminate the work of current $\mathrm{PhD}$ and MA students who were recruited through an open application process. Contacted by email after the events, the students' feedback on the experience confirmed that this safe space to present their work was valued. The authors noticed that academic research events such as conferences were often out of reach for postgraduate students. Therefore, it provided a platform for networking amongst established and early career researchers, and postgraduate students.

\subsection{Circular Design Lab Interest Group}

The CDL interest group was set up following the first edition of TABA help the conversation continue beyond a single event in the academic calendar. Open to any postgraduate student at the university, and advertised through internal newsletters, the group meetings occurred monthly during the academic terms and were designed to take different formats such as exhibition visits, guest speaker presentations, or brainstorming/mapping activities to explore the concept of circular design. Later in the year, these activities were cemented by 'circular surgeries' - one-to-one discussions to aid direct application into student work. One of the key aims of these activities was to draw students from all colleges and different courses together to create a network of circular design enthusiasts. This was seen as a valuable platform and a safe harbour to foster knowledge exchange between design disciplines.

\section{Bridging Research and Education}

One of the most popular research methodologies used by design-researchers globally is the Design Council's (2019) double diamond model. The model accomodates the widening and narrowing of the enquiry across four distinct stages: Discovering, Defining, Developing and Delivering. The first stage expands the enquiry, and scopes the field. This is followed by defining the enquiry to a specifc point. The third stage is to develop potential solutions, and is often done through ideating and making. Finally, the delivering stage incorporates reflection and feedback. The authors' design background is reflected in the way that the programme of CDL activities follows a double diamond structure.

\subsection{Discover}

Each year, the first stage of the programme was to offer the students the opportunity to discover and be inspired by new research in the form of talks from UAL researchers or external partners and 
presentations from current $\mathrm{PhD}$ students. In addition to activities that involved the students listening, explorative discovering was introduced through visits to trade shows and exhibitions. The curation of these complementary perspectives was key to widening the students' knowledge of circular design practice.

Table 1. CDL activities mapped across Design Council's (2019) stage - discover.

\begin{tabular}{|c|c|c|c|c|}
\hline \multicolumn{5}{|c|}{ DISCOVER } \\
\hline \multicolumn{5}{|c|}{ YEAR 1} \\
\hline TITLE & ACTIVITY & EVENT & DESCRIPTION & SPEAKER/LEADER \\
\hline $\begin{array}{l}\text { Introduction to the } \\
\text { research centre }\end{array}$ & $\begin{array}{l}\text { RESEARCH } \\
\text { TALK }\end{array}$ & TABA & $\begin{array}{l}\text { CCD projects and } \\
\text { strategy }\end{array}$ & Prof. B. Earley \\
\hline $\begin{array}{l}\text { Mistra Future Fashion } \\
\text { Research }\end{array}$ & $\begin{array}{l}\text { RESEARCH } \\
\text { TALK }\end{array}$ & TABA & $\begin{array}{l}\text { Project aims and interim } \\
\text { results }\end{array}$ & Dr Kate Goldsworthy \\
\hline $\begin{array}{l}\text { Trash } 2 \text { Cash: Fibre } \\
\text { Regeneration }\end{array}$ & $\begin{array}{l}\text { RESEARCH } \\
\text { TALK }\end{array}$ & TABA & $\begin{array}{l}\text { Project aims and interim } \\
\text { results }\end{array}$ & $\begin{array}{l}\text { Dr Dawn Ellams \& } \\
\text { Dr Rosie Hornbuckle }\end{array}$ \\
\hline $\begin{array}{l}\text { Mistra Future Fashion: } \\
\text { Manufacturing Tech }\end{array}$ & $\begin{array}{l}\text { RESEARCH } \\
\text { TALK }\end{array}$ & TABA & $\begin{array}{l}\text { Stakeholder networks in } \\
\text { the project }\end{array}$ & Dr Marion Real \\
\hline Design for Disassembly & PHD TALK & TABA & Interim PhD research & Laetitia Forst \\
\hline $\begin{array}{l}\text { Design for Mechanical } \\
\text { Textile Recycling }\end{array}$ & PHD TALK & TABA & Interim PhD research & Cathryn Hall \\
\hline Remanufacturing Fall Out & PHD TALK & TABA & Interim PhD research & Emmeline Child \\
\hline Circular.Fashion & $\begin{array}{l}\text { INDUSTRY } \\
\text { TALK }\end{array}$ & TABA & Industry project & Ina Budde \\
\hline \multicolumn{5}{|c|}{ YEAR 2} \\
\hline The Future Starts Here & VISIT & $\mathrm{CDL}$ & $\begin{array}{l}\text { Visit and discussion at } \\
\text { the V\&A museum }\end{array}$ & $\begin{array}{l}\text { Cathryn Hall and Dr } \\
\text { David Cross }\end{array}$ \\
\hline Fast and Light & $\begin{array}{l}\text { RESEARCH } \\
\text { TALK }\end{array}$ & $\mathrm{CDL}$ & $\begin{array}{l}\text { Presentation on the } \\
\text { topic of textile research }\end{array}$ & Prof. Kay Politowicz \\
\hline Future Fabric Expo & VISIT & $\mathrm{CDL}$ & $\begin{array}{l}\text { Visit of sustainable } \\
\text { textiles trade show }\end{array}$ & $\begin{array}{l}\text { Cathryn Hall and } \\
\text { Laetitia Forst }\end{array}$ \\
\hline Speeds and Slowness & $\begin{array}{l}\text { RESEARCH } \\
\text { TALK }\end{array}$ & TABA & $\begin{array}{l}\text { Talk on the philosophy } \\
\text { of speed in design }\end{array}$ & Jamie Brassett \\
\hline Loved Clothes Last -ECAP & $\begin{array}{l}\text { INDUSTRY } \\
\text { TALK }\end{array}$ & TABA & $\begin{array}{l}\text { Presentation of youth } \\
\text { awareness campaign }\end{array}$ & $\begin{array}{l}\text { Hannah Carter and } \\
\text { Ali Moore }\end{array}$ \\
\hline Circle Economy & $\begin{array}{l}\text { INDUSTRY } \\
\text { TALK }\end{array}$ & TABA & $\begin{array}{l}\text { Presenting a journey } \\
\text { toward circularity }\end{array}$ & Gwen Cunningham \\
\hline Trash to Cash & $\begin{array}{l}\text { RESEARCH } \\
\text { TALK }\end{array}$ & & $\begin{array}{l}\text { Project aims and interim } \\
\text { results }\end{array}$ & Prof. Becky Earley \\
\hline \multicolumn{5}{|c|}{ YEAR 3} \\
\hline $\begin{array}{l}\text { Here Today Here } \\
\text { Tomorrow }\end{array}$ & $\begin{array}{l}\text { INDUSTRY } \\
\text { TALK }\end{array}$ & $\mathrm{CDL}$ & $\begin{array}{l}\text { Challenges and } \\
\text { opportunities of } \\
\text { entrepreneurship }\end{array}$ & Julia Crew \\
\hline Future Fabric Expo & VISIT & $\mathrm{CDL}$ & $\begin{array}{l}\text { Visit of sustainable } \\
\text { textiles trade show }\end{array}$ & $\begin{array}{l}\text { Cathryn Hall and } \\
\text { Laetitia Forst }\end{array}$ \\
\hline
\end{tabular}




\begin{tabular}{lllll}
\hline A Transparent Company & $\begin{array}{l}\text { INDUSTRY } \\
\text { TALK }\end{array}$ & TABA & $\begin{array}{l}\text { Consultancy } \\
\text { presentation }\end{array}$ & Neliana Fuenmayor \\
\hline Extinction Rebellion & $\begin{array}{l}\text { INDUSTRY } \\
\text { TALK }\end{array}$ & TABA & Activism in fashion & Clare Farrell \\
\hline $\begin{array}{l}\text { Circular Change: } \\
\text { Department 22 }\end{array}$ & INDUSTRY & TABA & $\begin{array}{l}\text { Consultancy } \\
\text { presentation }\end{array}$ & Claire Brass \\
\hline $\begin{array}{l}\text { Textile Design for } \\
\text { Disassembly }\end{array}$ & ONLINE & CDL & $\begin{array}{l}\text { Presentation of interim } \\
\text { results }\end{array}$ & Laetitia Forst \\
\hline $\begin{array}{l}\text { Design for Mechanical } \\
\text { Textile Recycling }\end{array}$ & ONLINE & CDL & $\begin{array}{l}\text { Presentation of interim } \\
\text { results }\end{array}$ & Cathryn Hall \\
\hline
\end{tabular}

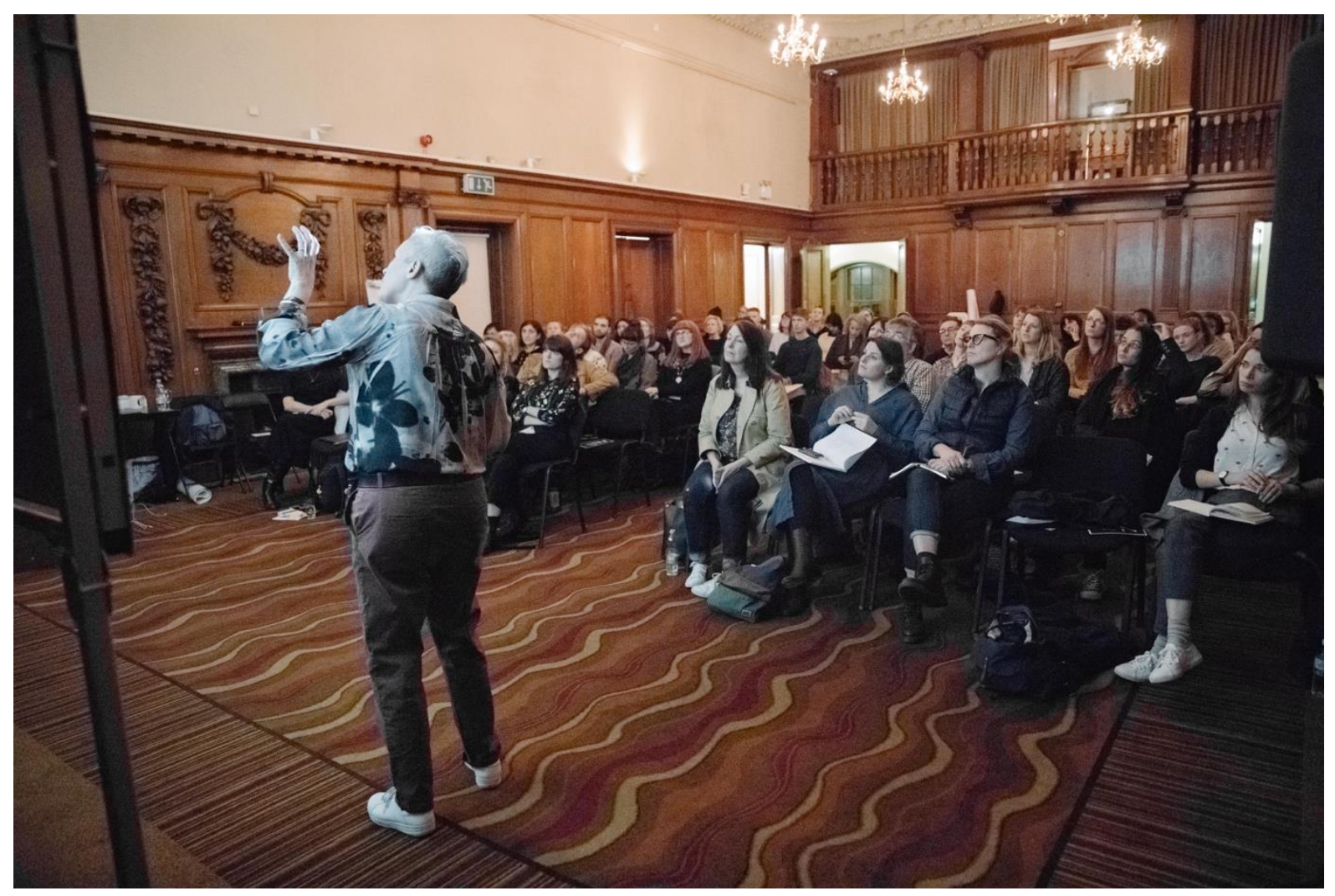

Figure 2. Keynote by Professor Becky Earley and Dr Kate Goldsworthy at TABA Year 2 


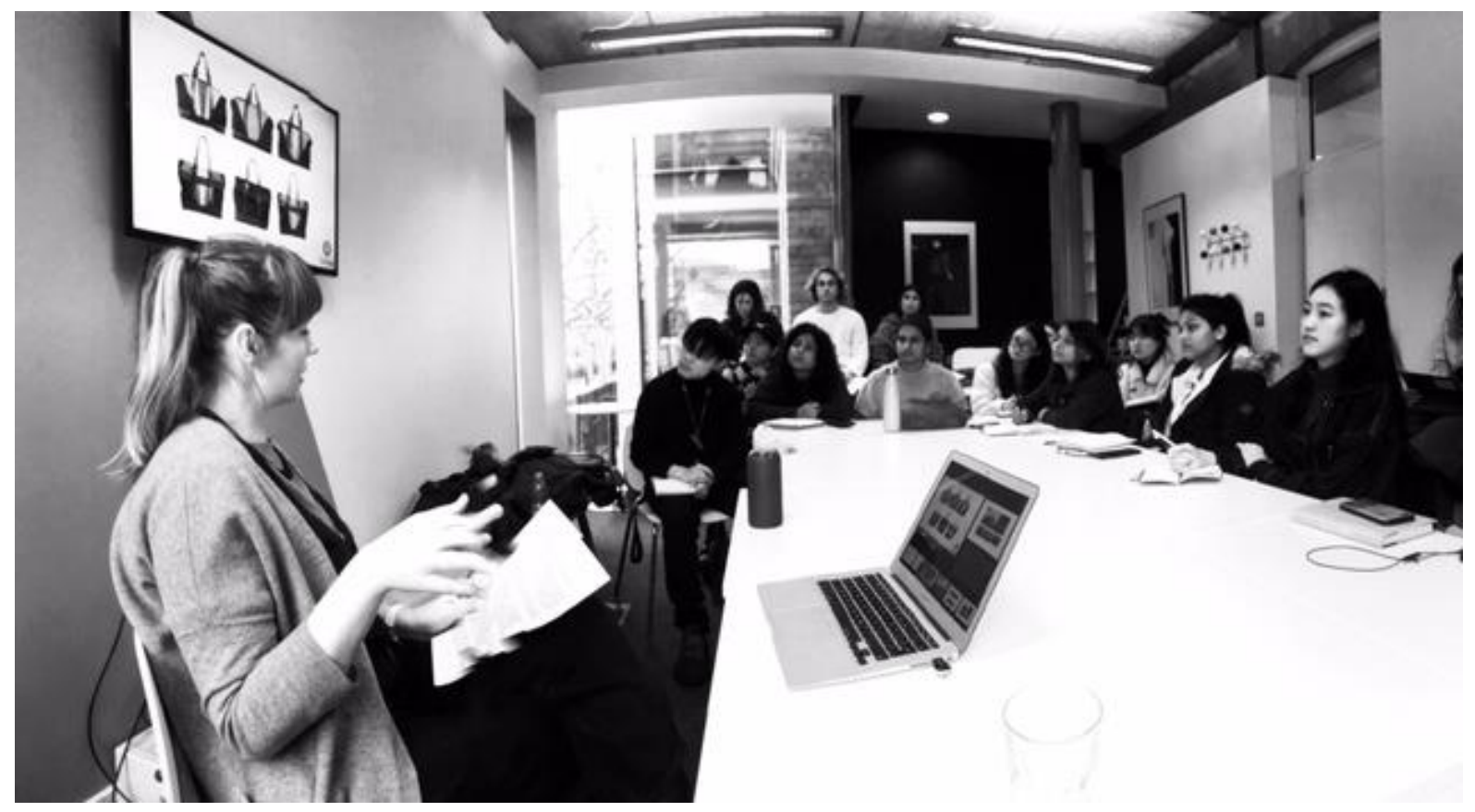

Figure 3. Here Today Here Tomorrow Talk at CDL Year 2

\subsection{Define}

The next stage of the programme aimed to define the key questions for circular designers to adopt in their work. Panel talks with speakers at the TABA symposiums were used to facilitate meaningful dialogue between students and experts. To this end the authors experimented with a live interview session with $\mathrm{PhD}$ researchers as an alternative to conventional talks.

A key element of this stage was the MA student speaker presentations at the TABA symposium. These were a response to the perceived lack of opportunities for post-graduate students to present work at research events. It provided a platform for selected students to present their research, often a work in progress, to a wider audience. These students were coached by the authors to refine their presentations content and skills. Senior researchers were invited to sit in the physical or virtual 'front row' to offer feedback as well as a Q\&A session with the audience.

Finally, students were able to situate their own work within current research models, such as in the 'Exploring Circles' session. Here, students were asked to position their work with the 'Materials, Model and Mindsets' Venn diagram (Earley, Vuletich, Goldsworthy, et al., 2016) as a method for facilitated discussion around circular design concepts.

Table 2. CDL activities mapped across Design Council's (2019) stage - define.

\begin{tabular}{lllll}
\hline \multicolumn{4}{c}{ DEFINE } \\
\hline TITLE & ACTIVITY & EVENT & DESCRIPTION & SPEAKER/LEADER \\
\hline There and Back Again & PANEL TALK & TABA & $\begin{array}{l}\text { Discussion between } \\
\text { PhDs and industry }\end{array}$ & Invited speakers \\
\hline
\end{tabular}




\begin{tabular}{|c|c|c|c|c|}
\hline $\begin{array}{l}\text { Reducing Ocean Plastic } \\
\text { through Print Design }\end{array}$ & MA TALK & TABA & Student presentation & Michaela Smith \\
\hline $\begin{array}{l}\text { Anarchism for Community- } \\
\text { led Textile Design }\end{array}$ & MA TALK & TABA & Student presentation & Eleanor Tull \\
\hline Creative Ecologies & MA TALK & TABA & Student presentation & Max Effantin \\
\hline $\begin{array}{l}\text { Interior Greenhouse } \\
\text { Project }\end{array}$ & MA TALK & TABA & Student presentation & $\begin{array}{l}\text { Eloise Morant \& } \\
\text { Hanna Riyanto }\end{array}$ \\
\hline Practice What You Teach & MA TALK & TABA & Student presentation & Michael Beaney \\
\hline \multicolumn{5}{|c|}{ YEAR 2} \\
\hline The Future is Circular & DISCUSSION & $\mathrm{CDL}$ & Discussing aims of CDL & $\begin{array}{l}\text { Cathryn Hall and } \\
\text { Laetitia Forst }\end{array}$ \\
\hline Sustainability and Activism & DISCUSSION & $\mathrm{CDL}$ & $\begin{array}{l}\text { Discussing } \\
\text { Decarbonisation }\end{array}$ & David Cross \\
\hline $\begin{array}{l}\text { Fatbergs, polyester, and } \\
\text { the super-fast wipe }\end{array}$ & MA TALK & TABA & Student presentation & Kath Lovett \\
\hline $\begin{array}{l}\text { What will we leave for the } \\
\text { next generation? }\end{array}$ & MA TALK & TABA & Student presentation & Kejun Lui \\
\hline Bio-Iridescent Sequin & MA TALK & TABA & Student presentation & Elissa Brunato \\
\hline Circular Wardrobe & $\begin{array}{l}\text { PHD } \\
\text { INTERVIEW }\end{array}$ & TABA & $\begin{array}{l}\text { Follow-up interview } \\
\text { after presentation }\end{array}$ & Lynn Wilson \\
\hline \multicolumn{5}{|c|}{ YEAR 3} \\
\hline Exploring Circles & $\begin{array}{l}\text { MAPPING } \\
\text { WORKSHOP }\end{array}$ & $\mathrm{CDL}$ & $\begin{array}{l}\text { Mapping student } \\
\text { projects on CCD } \\
\text { framework }\end{array}$ & Cathryn Hall \\
\hline $\begin{array}{l}\text { Circular biomimetic } \\
\text { textiles }\end{array}$ & MA TALK & TABA & Student presentation & Cassie Quinn \\
\hline Potato Money & MA TALK & TABA & Student presentation & $\begin{array}{l}\text { Holly English \& } \\
\text { Claudia Sambo }\end{array}$ \\
\hline Dewaste your Taste & MA TALK & TABA & Student presentation & Rebecca Ghim \\
\hline Fibre Lab Collective & MA TALK & TABA & Student presentation & Kaela Katz \\
\hline Holistic System Symbiotic & $\begin{array}{l}\text { PHD TALK + } \\
\text { Q\&A }\end{array}$ & TABA & Interim result discussion & Loula Mercedes \\
\hline Teaching Change Making & DISCUSSION & TABA & $\begin{array}{l}\text { Online discussion of CDL } \\
\text { programme }\end{array}$ & $\begin{array}{l}\text { Cathryn Hall and } \\
\text { Laetitia Forst }\end{array}$ \\
\hline
\end{tabular}




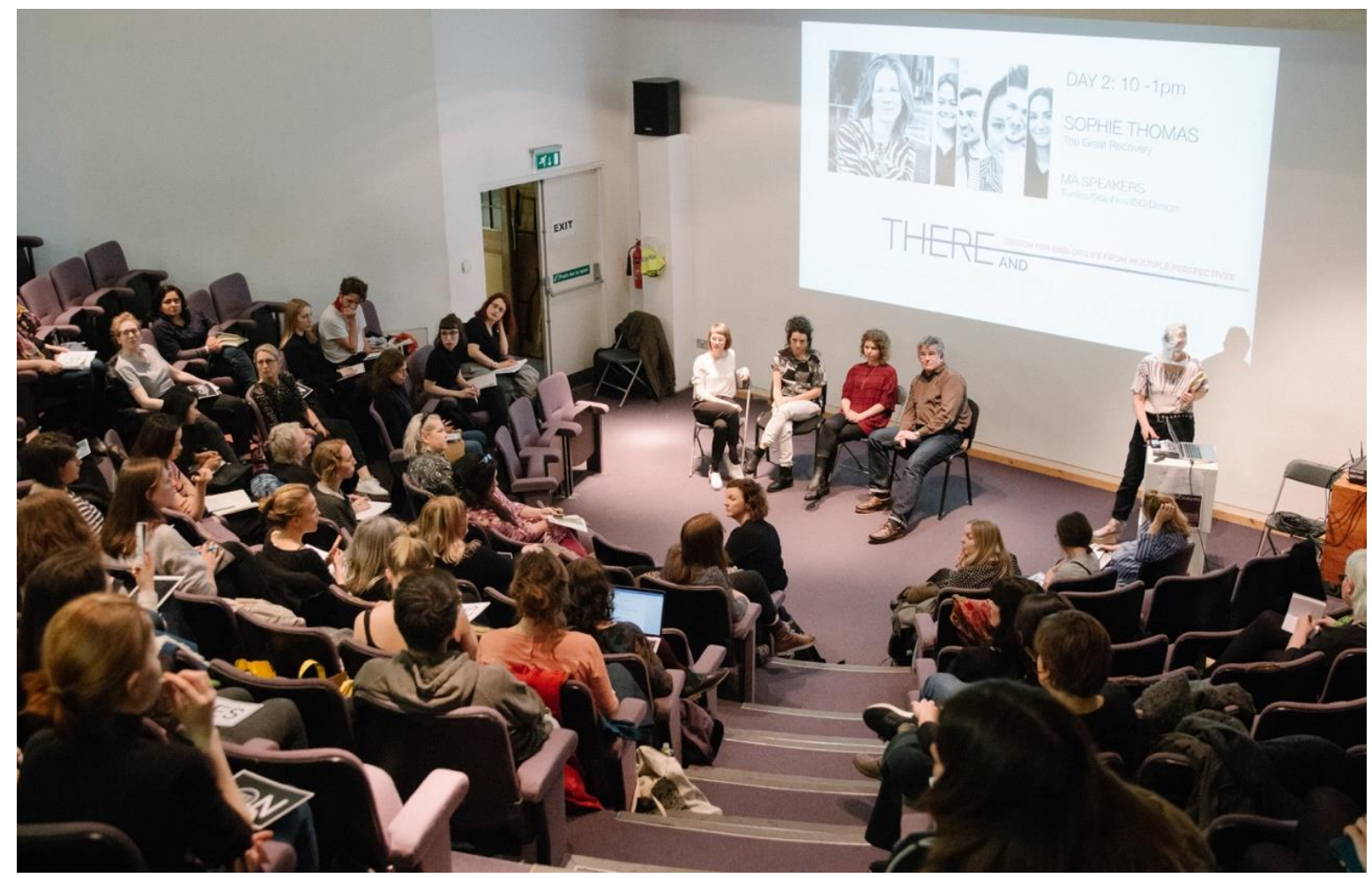

Figure 4. Panel talk at TABA Year 1

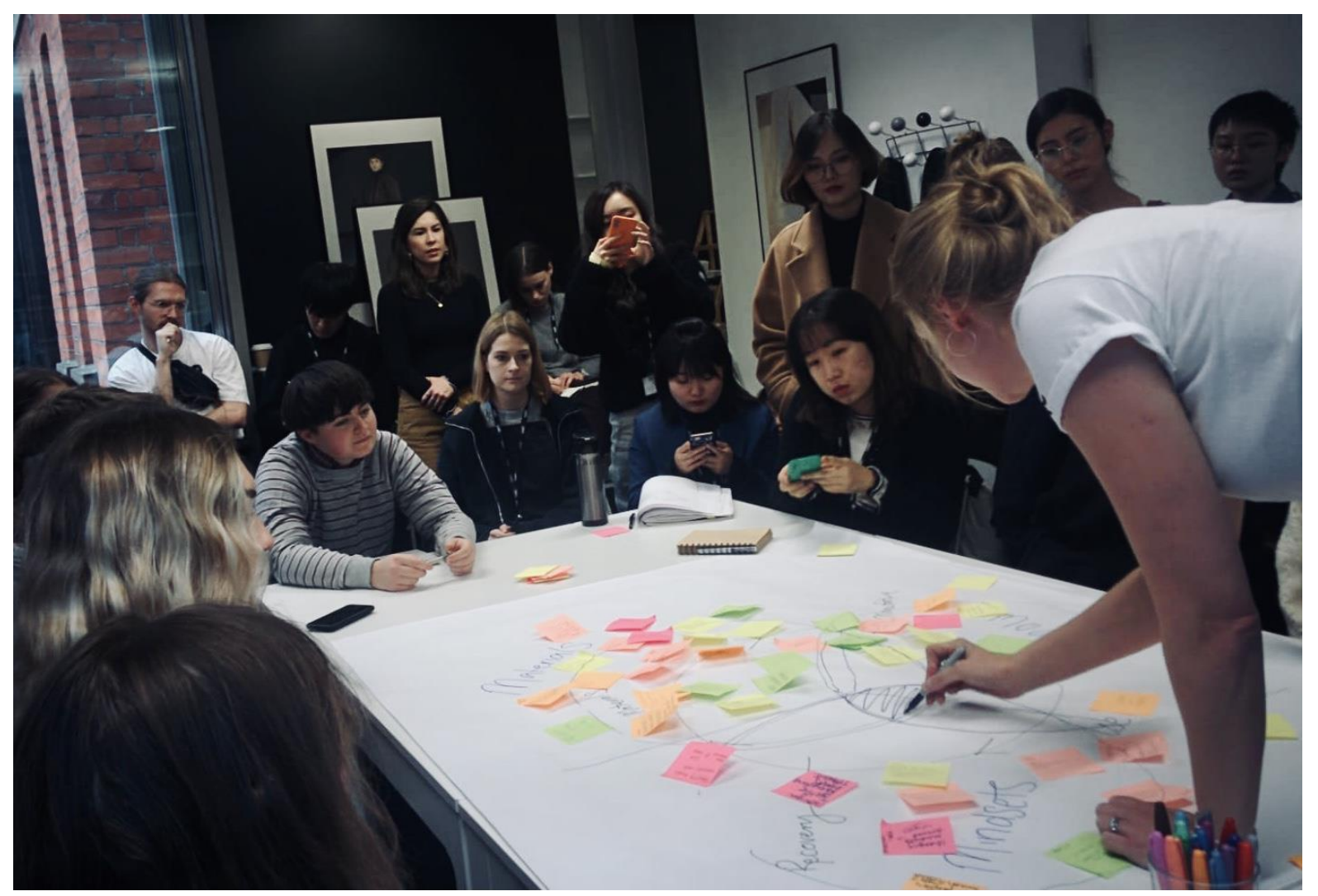

Figure 5. CDL Year 3 'Exploring Circles' 


\subsection{Develop}

The developing stage of the model is focused on ideating and prototyping. While physical making was never part of the CDL activities, ideating and discussing the making in its many forms developed across the three years. In Year 1, workshops were included to support students and industry attendees in re-imagining products and systems in line with circular principles. This was developed the next two years with the addition of a pop-exhibition at the TABA event where protypes and fabric sample could be viewed to reinforce insights from the discovery and defining stages.

This was further expanded with 'Circular Surgeries', 1-2-1 sessions to review and discuss students practice through a circular design lens. Students from all disciplines, such as theatre, architecture, photography, textiles, fashion, design management, etc, attended to receive mentoring from the authors in their role as PhD students.

Table 3. CDL activities mapped across Design Council's (2019) stage - develop.

\begin{tabular}{|c|c|c|c|c|}
\hline \multicolumn{5}{|c|}{ DEVELOP } \\
\hline \multicolumn{5}{|c|}{ YEAR 1} \\
\hline TITLE & ACTIVITY & EVENT & DESCRIPTION & SPEAKER/LEADER \\
\hline Design for Recycling & WORKSHOP & TABA & $\begin{array}{l}\text { Collaborative ideation } \\
\text { workshop }\end{array}$ & Cathryn Hall \\
\hline Fab Hack & WORKSHOP & TABA & $\begin{array}{l}\text { Collaborative ideation } \\
\text { workshop }\end{array}$ & Laetitia Forst \\
\hline \multicolumn{5}{|c|}{ YEAR 2} \\
\hline Design for Recycling & WORKSHOP & TABA & $\begin{array}{l}\text { Collaborative ideation } \\
\text { workshop }\end{array}$ & Cathryn Hall \\
\hline Fab Hack & WORKSHOP & TABA & $\begin{array}{l}\text { Collaborative ideation } \\
\text { workshop }\end{array}$ & Laetitia Forst \\
\hline Circular Speeds & WORKSHOP & TABA & $\begin{array}{l}\text { Collaborative ideation } \\
\text { workshop }\end{array}$ & $\begin{array}{l}\text { Cathryn hall and } \\
\text { Laetitia Forst }\end{array}$ \\
\hline $\begin{array}{l}\text { Trash to Cash and MFF } \\
\text { showcase }\end{array}$ & EXHIBITION & TABA & $\begin{array}{l}\text { Pop up show of samples } \\
\text { and posters }\end{array}$ & N/A \\
\hline Circular Surgeries & SURGERY & $\mathrm{CDL}$ & $\begin{array}{l}\text { One to one mentoring } \\
\text { with students }\end{array}$ & $\begin{array}{l}\text { Cathryn Hall and } \\
\text { Laetitia Forst }\end{array}$ \\
\hline \multicolumn{5}{|c|}{ YEAR 3} \\
\hline Circular Surgeries & SURGERY & $\mathrm{CDL}$ & $\begin{array}{l}\text { One to one mentoring } \\
\text { with students }\end{array}$ & $\begin{array}{l}\text { Cathryn Hall and } \\
\text { Laetitia Forst }\end{array}$ \\
\hline Circular Surgeries (online) & SURGERY & $\mathrm{CDL}$ & $\begin{array}{l}\text { One to one mentoring } \\
\text { with students }\end{array}$ & $\begin{array}{l}\text { Cathryn Hall and } \\
\text { Laetitia Forst }\end{array}$ \\
\hline Circular Actions & WORKSHOP & TABA & $\begin{array}{l}\text { Online collaborative } \\
\text { ideation workshop }\end{array}$ & $\begin{array}{l}\text { Cathryn Hall and } \\
\text { Laetitia Forst }\end{array}$ \\
\hline
\end{tabular}




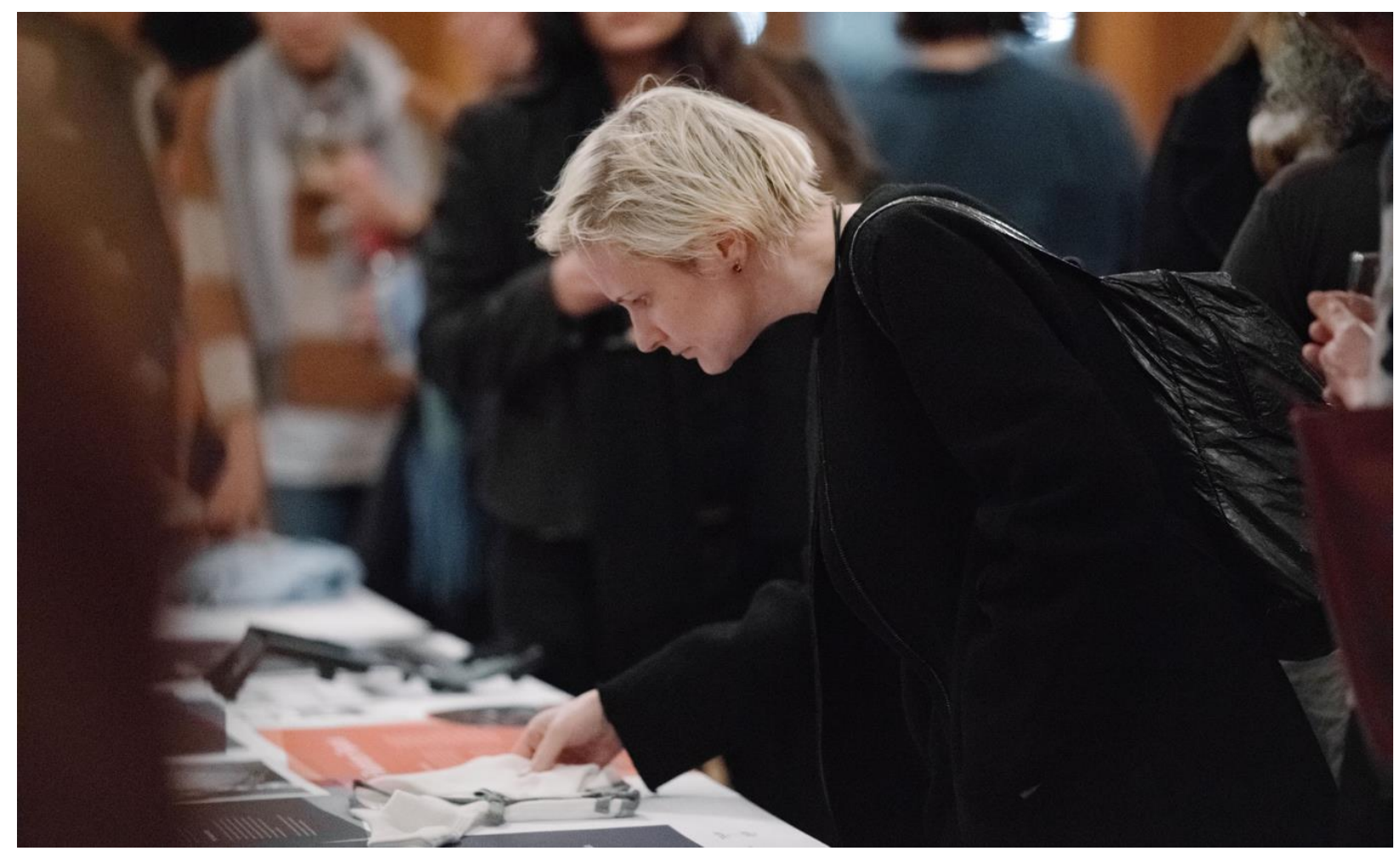

Figure 6. Pop-up exhibition at TABA 2

\subsection{Deliver}

The final stage of the Design Council's double diamond model is delivery. While this usually refers to delivering a final product, here it is considered as part of the reporting on the full programme which provides the basis for reflection and improvements through iteration. Each year a complete report was provided and the third (virtual event adapted because of the pandemic) was fully recorded and is available to watch back online.

Reflection on the broader context of the activities was also key. For example, the second version of TABA was specifically designed to contribute to the university research centre objectives to create and nourish: impact, inter-disciplinarity, research, networks, knowledge exchange, teaching and tools. For the student audience, CDL was designed to provide broad range of perspectives to supplement the content of taught courses. 

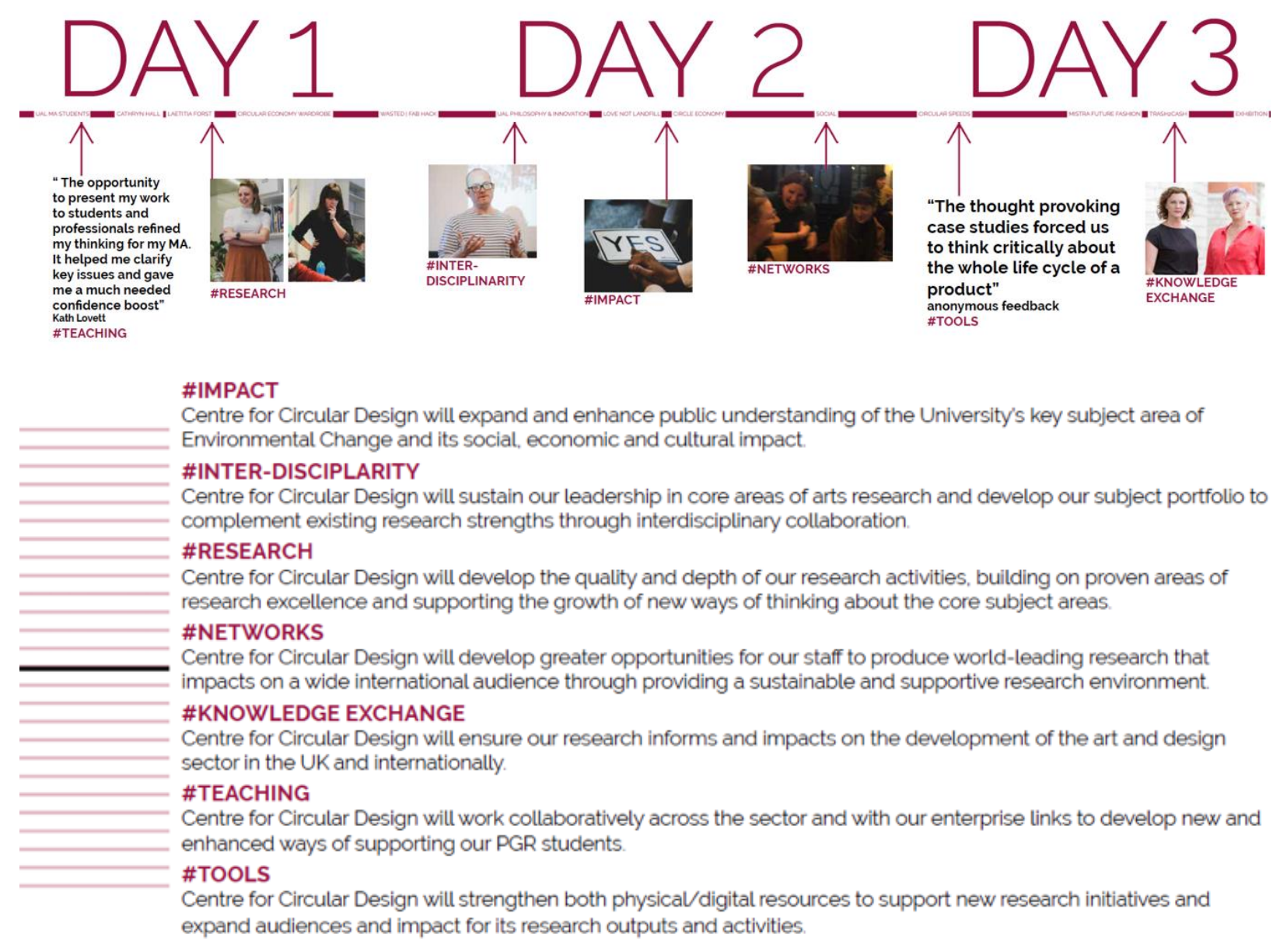

Figure 7. Reporting on TABA 2 visually demonstrating the events design to contribute to the requirements of the UAL research centres objectives

\section{Enablers \& Limitations}

The CDL programme didn't happen in isolation. The conditions needed to be just right for the ideas that underpinned the activities to come to life. By reflecting on what seemed to happen naturally, key enablers are identified: the supportive environment of the research centre, the thriving network of researchers in and beyond the university, the chance collaboration of two full-time funded PhD students. While these were enablers, they also act as limitations for replicating these types of activities to bridge research and education through practice methods. Yet, identifying these elements can reveal some of the key decisions that could be made to support such programmes and give them lasting presence in a thriving research and knowledge exchange context.

\subsection{Support from the Research Centre}

The first key enabler was the support provided by the directors, administrators, and project researchers at the CCD who considered this student-led work as a valuable contribution to the centre's culture. University research centres, thrive with external networks and communities which are described as the lifeblood of research for a circular economy, and where ideas are often applied (Earley, 2018). The research produced in this context is regularly conducted in collaboration with 
industry partners. Thus, the centre provided a network of experts to draw from for talks, as well as an audience already attuned to the circular design conversation. Lack of support from research centres could therefore hinder the development of PhD student-led activities.

\subsection{Support from the University}

The broader context of the university played an important role in bringing to life the CDL vision. The support of the post-grad community network demonstrated a readiness to engage with extracurricular activities in this topic. CDL activities were validated by the university's strategy for funding internal projects. Not only did it respond to priorities connected to the climate emergency, but it also fitted with ambitions to support collaborative work between courses and colleges. It is acknowledged that without the financial and administrative support of the university, none of the work would have been possible and there a strong case that any support received by the university can in turn be beneficial to the institution in furthering its reputation for excellence in research and knowledge exchange.

\subsection{Fully Funded PhD}

Within this favourable context, the trigger for the development of CDL came from the coincidental collaboration between two PhD students (authors of this paper) carrying out their circular textile design research at the same time and place. Importantly, when considering the legacy of such work, both authors were fully funded for their PhD work, representing a minority of cases in art and humanities research (British Academy, 2012). This provided time and headspace to carry out work separate from the thesis, as well as a sense of 'wanting to give back' to the university.

While it is essential to provide opportunities for PhD students to engage with their research community (Horta, Cattaneo and Meoli, 2018), the legacy of this type of activity can come into question. Whether this type of activity can be passed from student to student could be achieved through doctoral funding but also other types of support as discussed above. Investment from universities and external funding bodies stands to benefit student body beyond the individual PhD experience (Hawthorne and Fyfe, 2015).

\section{Discussion: The Role of Design}

This paper argues that design-based methods, particularly practice-based ones, can be used in an adaptive approach to foster research and student communities within a university. Following a wellknown double diamond method the programme widens then refines students enquiry of new research ideas. The participative format, as opposed to prescriptive tools, suports the discussion of complex and intersectional themes in the field of circular design.

We argue that the author's background in textile design and their familiarity with practice research approaches such as the bricolage method, has largely contributed to the success of the programme and to its potential legacy for teaching circular design. Being a circular textile designer acknowledges the complexity of many supply chains and end of life trajectories, taking on technical challenges, understanding networks and systems to develop solutions to current environmental issues (Lerpiniere, 2020). This way of embracing ambiguity and recognising patterns in complex systems 
provides designers with the tools to develop valuable knowledge exchange material such as the CDL programme. It also ensures that these types of activities can thrive in unexpected contexts - such as a global pandemic.

Current conversations in the field acknowledge the value of different types of practice, ranging from embodied knowledge in craft (Tsutsumi, 2018), to the shift of designers' roles as leaders and facilitators (Earley, 2018). It is the practitioner's way of thinking, to expand on Cross's (2007) designerly ways of thinking, infused in all activities, from crafting a presentation to curating guest speaker talks that enabled the CDL programme to succeed.

This expanded role of the designer extends to that of a boundary spanner. As suggested by Hornbuckle (2010), a designer's skill make them uniquely apt to bridge gaps in communication. Here the PhD students, supported by UAL and CCD were able to act as the link or 'linkage actor' (Becheikh et al., 2010) between research and teaching. While we acknowledge the need for support (financial and other) by the university and research centres in enabling CDL's success, the different types of activities provided spaces for knowledge exchange in the form of debate, discussion and the rare opportunity for students to present their own work directly to academic researchers rather than teaching staff. It is this combination of approaches, from adaptive designerly methods to fostering knowledge exchange that enabled the PhD students to act as a bridge between research and teaching communities to teach circular design.

\section{Conclusion}

The CDL programme emerged because of the perceived need to connect students to the research community. This gap was successfully bridged through practice-based methods the CDL symposium and interest group which connected students to the research in new ways such as giving them opportunities to participate in PhD-led workshops or to present their own work. CDL provided an environment for discussion and debate on the topic of circular design.

Reflecting on the programme of activities as design practice showed how CDL was curated to be adaptive and to thrive in unexpected contexts - such as a global pandemic. It was found that the activities naturally fell into the double diamond approach: discover, define, develop, and deliver. This can act as a legacy for similar programmes in other institutions to support knowledge exchange for circular design and provide the opportunity to connect with post-graduate courses which have overlapping interests. It is acknowledged that for this to succeed adequate support must be provided by the university and research communities. Finally, it is the role of practice-based PhD students acting as a bridge between students and research that produced a culture of knowledge exchange and enabled the successful way of teaching circular design.

\section{References}

Becheikh, N., Ziam, S., Idrissi Fakhreddine, M., Castonguay, Y. and Landry, R. (2010) 'How to improve knowledge transfer strategies and practices in education? Answers from a systematic literature review', Research in Higher Education Journal, 7. Available at:

https://www.aabri.com/manuscripts/09418.pdf (Accessed: 23 August 2021).

Braungart, M. and McDonough, W. (2002) Cradle to Cradle. Remaking the Way We Make Things. 1st Edition. New York: North Point Press. 
British Academy (2012) Position Statement: Postgraduate funding - the neglected dimension. Available at: https://postgraduateworker.files.wordpress.com/2012/07/british-academy-positionstatement.pdf (Accessed: 14 June 2021).

Centre for Circular Design (2021) The TEN - Can a pack of cards be used as a tool for change?, The TEN. Available at: https://www.circulardesign.org.uk/research/ten/ (Accessed: 9 April 2021).

Cross, N. (2007) Designerly ways of knowing. Basel: Birkhäuser.

Design Council (2019) What is the framework for innovation? Design Council's evolved Double Diamond, Design Council. Available at: https://www.designcouncil.org.uk/news-opinion/whatframework-innovation-design-councils-evolved-double-diamond (Accessed: 6 July 2020).

Design School Kolding (2018) Sustainable Design Cards - Approaches to Sustainable Design, Sustainable Design Cards. Available at: https://sustainabledesigncards.dk/ (Accessed: 9 April 2021).

Earley, R. (2018) 'Whole Circles: A Leadership Model to Support Expanded Roles for Circular Textile Designers', Journal of Textile Design Research and Practice, 6(1), pp. 112-136. doi: 10.1080/20511787.2018.1434744.

Earley, R. and Forst, L. (2019) 'Everything That Went Wrong: challenges and opportunities in designing and prototyping long-life garments in a circular economy', in 3rd PLATE 2019 Conference Proceedings. PLATE: Product Lifetimes and The Environment, Berlin, Germany: PLATE Conference. Available at: https://www.circulardesign.org.uk/documents/7/EverythingThatWentWrong_PlatePaper.pdf (Accessed: 30 November 2020).

Earley, R., Vuletich, C., Goldsworthy, K., Politowicz, K. and Ribul, M. (2016) Textile Toolbox: New Design Thinking, Materials \& Processes for Sustainable Fashion Textiles Project Report (20112015). Sweden: MISTRA. Available at:

http://www.textiletoolbox.com/media/uploads/report01/mistra-textile-toolbox-project-report2011-2015.pdf (Accessed: 10 April 2021).

Earley, R., Vuletich, C., Hadridge, P. and Reitan Andersen, K. (2016) 'A New “T” for Textiles: Training Design Researchers to Inspire Buying Office Staff Towards Sustainability at Hennes and Mauritz (H\&M)', The Design Journal, 19(2), pp. 301-321. doi: 10.1080/14606925.2016.1130380.

EMF (2013) Towards the circular economy: Economic and business rationale for an accelerated transition. 1. London: Ellen Macarthur Foundation, pp. 23-44. Available at: https://www.ellenmacarthurfoundation.org/assets/downloads/publications/Ellen-MacArthurFoundation-Towards-the-Circular-Economy-vol.1.pdf (Accessed: 1 June 2019).

EMF (2017) Discover the circular economy, Learning Hub. Available at: https://www.ellenmacarthurfoundation.org/explore (Accessed: 9 April 2021).

Follett, G. and Marra, M. (2012) 'Design in Action - Building a model for knowledge exchange between industry and academia, using design as a strategy for business growth in Scotland', in Proceedings of the DMI 2012 International Research Conference. Leading Innovation through Design - Design Management Research Conference, Boston, USA: Design Management Institute. Available at: http://www.dmi.org/dmi/html/conference/academic12/AC12Proceedings.pdf (Accessed: 9 January 2021).

Forst, L. (2020) Textile Design for Disassembly. PhD Thesis. University of the Arts London.

Hall, C. A. (2021) Design for Recycling Knitwear. PhD Thesis (pre-publication). University of the Arts London.

Hasling, K. and Ræbild, U. (2018) 'Sustainable Design Cards: A Learning Tool for Supporting Sustainable Design Strategies', in Sustainable Fashion in a Circular Economy. Aalto, Finland: Aalto University, pp. 128-151.

Hawthorne, T. L. and Fyfe, D. (2015) 'The importance of student-led initiatives in rethinking the Ph.D.', GeoJournal, 80(2), pp. 175-179. doi: 10.1007/s10708-014-9584-4. 
Hornbuckle, R. (2010) Design and the Material Cycle: An Investigation into Secondary Material Use in Design Practice. PhD Thesis. Kingston University.

Horta, H., Cattaneo, M. and Meoli, M. (2018) 'PhD funding as a determinant of PhD and career research performance', Studies in Higher Education, 43(3), pp. 542-570. doi: 10.1080/03075079.2016.1185406.

Irwin, T., Kossoff, G. and Tonkinwise, C. (2015) 'Transition Design Provocation', Design Philosophy Papers, 13(1), pp. 3-11. doi: 10.1080/14487136.2015.1085688.

Joāo, E. (2020) Educational materials on sustainability, circular economy and bioeconomy for schools, colleges and universities. EU Horizon 2020: Be Rural: Bio-based strategies and roadmaps for enhanced rural and regional development in the EU. Glasgow, Scotland: University of Strathclyde. Available at: https://be-rural.eu/wp-content/uploads/2020/10/Educational-materials-onsustainability-word-version-v2_reduced.pdf (Accessed: 9 April 2021).

Joore, P., Crul, M., Celik, S., Bakirlioglu, Y., Blackmore, E., DeEyto, A., Gisslen, A. V., Habermann, K., Jimenez, A., Lazzarini, B., Martens, J., McMahon, M., Obiols, A., O'Donnell, P., O'Riain, M., Ozkan, N., Santamaria, M., Segalas, J., Tejedor, G., Trullols, E. and Wever, R. (2019) Teaching Circular Design - A Handbook for Educators. Universitat Politecnica de Catalunya, Barcelona, Spain. Available at: http://circulardesigneurope.eu/wp-content/uploads/2020/01/Handbook-in-IDfS.pdf (Accessed: 10 April 2021).

Kirchherr, J. and Piscicelli, L. (2019) 'Towards an Education for the Circular Economy (ECE): Five Teaching Principles and a Case Study', Resources Conservation and Recycling, 150, p. 104406. doi: 10.1016/j.resconrec.2019.104406.

Lerpiniere, C. (2020) 'Value Definition in Sustainable (Textiles) Production and Consumption', in Granger, R. (ed.) Value Construction in the Creative Economy. Palgrave Macmillan, Cham: Palgrave Studies in Business, Arts and Humanities, pp. 85-107.

Mainsah, H., Morrison, A. and Edeholt, H. (2017) 'Building networks for knowledge exchange, and design strategies for climate futures', The Design Journal, 20(sup1), pp. S102-S109. doi: 10.1080/14606925.2017.1352660.

Morrison, J. E. and Meliza, L. L. (1999) Foundations of the After Action Review Process. IDA/HQD2332. INSTITUTE FOR DEFENSE ANALYSES ALEXANDRIA VA. Available at: https://apps.dtic.mil/docs/citations/ADA368651 (Accessed: 14 June 2021).

Tsutsumi, M. (2018) 'Thoughts and Utterances in Material Practice: Objects and Words / Thoughts and Actions', in. Utsuwa Utsumi, Chelsea College of Arts. Available at: https://ualresearchonline.arts.ac.uk/id/eprint/13128/ (Accessed: 12 July 2021).

Whitty, J. (2016) 'Operating in the Third Space: the space between', in Circular Transitions Proceedings. Circular Transitions, London, UK: Centre for Circular Design, pp. 20-31. Available at: http://circulartransitions.org/media/downloads/Circular-Transitions-Proceedings.pdf (Accessed: 27 February 2020).

Author Bios:

Dr Laetitia Forst completed her PhD on Textile Design for Disassembly in December 2020. Since then she has been a post-doctoral research fellow at UAL, working on the ULRI funded Business of Fashion and Textiles (BFTT) project with the Centre for Sustainable Fashion and on the EU Horizon 2020 funded HEREWEAR project with the Centre for Circular Design

Cathryn Anneka Hall Postdoctoral Research Fellow at University of Arts London (UAL) currently working on the Bio-Inspired Textile research project. She recently submitted her PhD thesis 'Design for Recycling Knitwear' with the Centre for Circular Design. Cathryn's 
Bridging Practice: Design lessons for knowledge exchange between students and research in circular design

practice research centres on how design can be used to extend the life of textile resources in the transition to a circular economy.

Acknowledgements: The authors gratefully acknowledge the funding provided by University of the Arts London and support of Centre for Circular Design without which the Circular Design Lab activities this paper is based on would not be possible. 